УДК 662.995:662.997

\title{
Експлуатаційні характеристики полімерних сонячних колекторів для адсорбційних холодильних геліоустановок
}

\author{
К.М. Сухийа \\ аВНЗ «Український державний хіміко-технологічний університет», Дніпро \\ ${ }^{6}$ Національна Металургійна Академія України, Дніпро

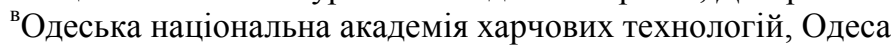

\begin{abstract}
Вивчені експлуатаційні характеристики сонячних колекторів, які виготовлені зі стільникових полікарбонатних пластиків, для адсорбиійних холодильних установок. Проведені натурні випробування розроблених колекторів ПСК-АB2-3, ПСК-AB1-2, ПСК-АВ2-1, ПСК-BC1-2, ПСК-BC2-2, ПСК-ВС2-3, ПСК-СТ10-ЧВ. Показана кореляція їх результатів з лабораторними випробуваннями за допомогою теплогідравлічного стенду. Визначені оптичний коефіцієнт корисної дї̈ та приведений коефічієнт теплових втрат полімерних сонячних колекторів. На основі залежностей коефіцієнта корисної дї сонячних колекторів від приведеної температури визначені оптимальні конструкиії полімерних сонячних колекторів для адсорбиійних холодильних геліоустановок в залежності від температури регенерації сорбентів. Показано, щзо при температурі регенерації композитного сорбенту до 50 - $60^{\circ} \mathrm{C}$ доцільно використовувати колектори типу - ПСК-АВ2-1, ПСК-СТ10-ЧВ, а при температуpax, вище $80^{\circ} C$ - типів ПСК-AB2-3, ПСК-BC2-3, ПСК-AB1-2, ПСК-BC2-2 та ПСК-BC1-2. Показана перспективність використання полімерних сонячних колекторів при конструюванні адсорбиійних холодильних установок.
\end{abstract}

Ключеві слова: адсорбиійна холодильна геліосистема; полімерний сонячний колектор; стільниковий полікарбонатний пластик.

(C) The Author(s) 2018. This article is an open access publication

This work is licensed under the Creative Commons Attribution 4.0 International License (CC BY)

http://creativecommons.org/licenses/by/4.0/

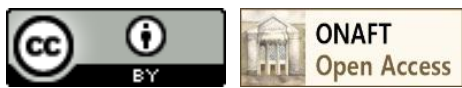

\section{1 Вступ}

Адсорбційні холодильні геліоустановки $є$ одними 3 найперспективніших альтернативних систем адсорбційного перетворення теплової енергії $[1,2]$. Їх широке впровадження дозволить істотно знизити сезонне перевантаження енергосистем в літній період. Основними конструктивними елементами адсорбційної холодильної установки є адсорбер, до якого здійснюється підведення енергії ззовні за рахунок утилізації низькопотенційних енергоресурсів та нетрадиційних джерел енергії, зокрема, сонячної, конденсатор і холодильна камера, біля якої розміщено випарник [2]. В холодильних геліоустановках підведення теплової енергії здійснюється за допомогою сонячного колектора. Вочевидь одним 3 ключевих факторів, що визначають експлуатаційні характеристики сонячної адсорбційної холодильної установки $є$ конструкція сонячного колектора. Найпростішим за конструкцією та експлуатацією є плоскі металеві сонячні колектори [3]. Але їх висока вартість стимулює розробку вдосконалених сонячних колекторів на основі нових матеріалів, зокрема полімерів, які виявили свою ефективність в системах теплопостачання.

Метою даної роботи є дослідження полімерних сонячних колекторів, визначення їх теплотехнічних характеристик та вибір оптимальної конструкції для адсорбційної геліоустановки.

\section{2 Методика експерименту}

Експериментальні випробування розроблених полімерних СК складалися з натурних і лабораторних випробувань СК. Лабораторні випробування проводили за допомогою тепло гідравлічного стенду, конструкція якого представлена на рис. 1

Натурні випробування проводились 19 червня 2017 року в місті Дніпро (Дніпропетровськ) опівдні. Температура навколишнього середовища складала $\mathrm{t}_{0}=25^{\circ} \mathrm{C}$, a температура на вході в $\mathrm{CK} \mathrm{t}_{\mathrm{Bx}}=27^{0} \mathrm{C}$. Середнє значення повного сонячного випромінювання на горизонтальну поверхню становило $\mathrm{H}=761,514 \mathrm{BT} / \mathrm{M}^{2}$.

Лабораторні випробування проводились за допомогою теплогдравлічного дослідного стенду згідно [4]. Згідно рис. 26 у випробувальному коробі міститься дослідний СК, 3 імітатором сонячного випромінювання (1). Бак постійного рівня (2) 3 переливною трубою (3) розташований вище СК. Зливальний бак (4) розташований нижче СК, у який надходить теплоносій 3 теплоізольованого бака постійного рівня через переливну трубу. Циркуляційний насос (5) встановлений у контурі, що з'єднує зливальний бак з баком постійного рівня, забезпечує перекачування теплоносія зі зливального бака у верхній бак з витратою, що перевищує витрату теплоносія через СК для підтримки постійного рівня теплоносія в баку. Вентиль (6) встановлений у розімкнутому контурі подачі теплоносія 3 бака постійного рівня на вхід СК для регулювання гідравлічного опору й витрати теплоносія. Проточний термостат (7), установлений на ділянці перекачування теплоносія зі зливального бака в бак постійного рівня, забезпечує термостатування теплоносія 3 точністю меншою, чим необхідна точність підтримки температури на вході в СК (8). Вимірювання щільності потоку штучного випромінювання здійснювалось піранометром Kipp \& Zonen CM21. 


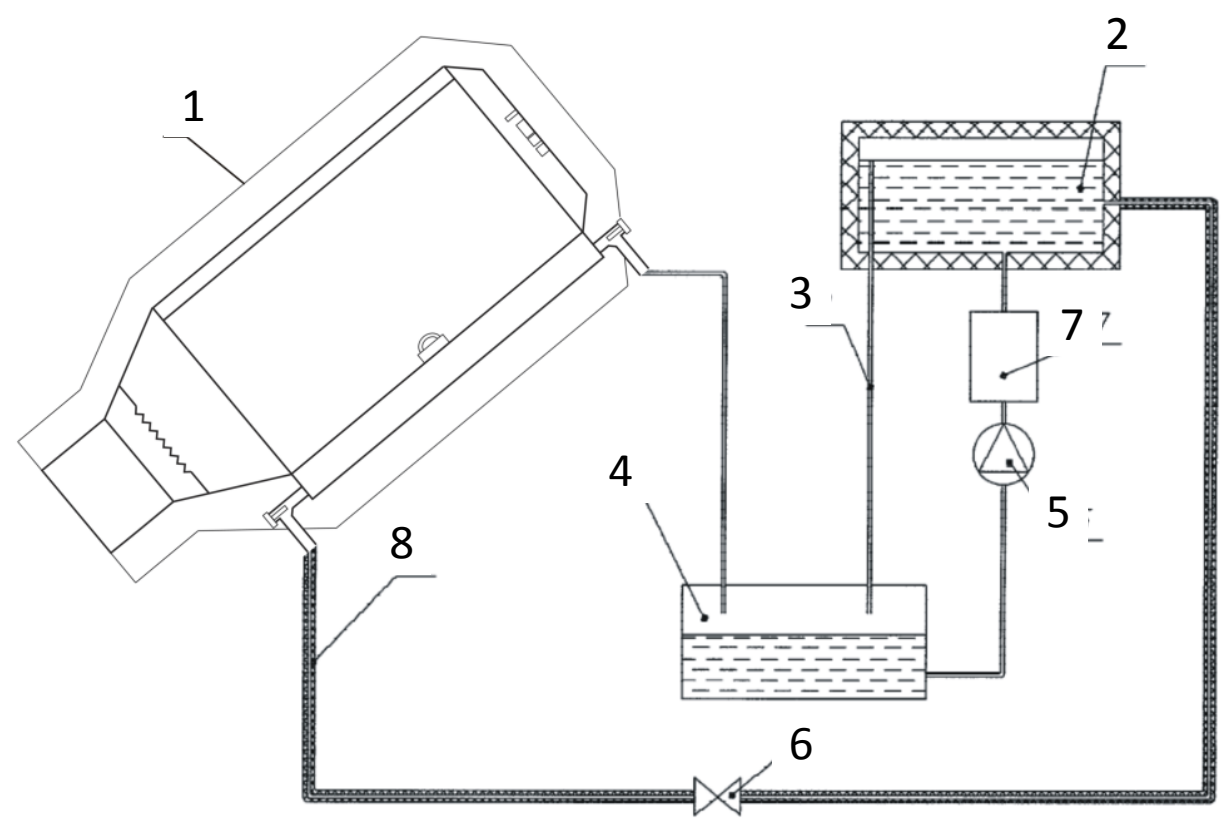

1 - випробувальний короб; 2 - теплоізольований бак постійного рівня; 3 -переливна труба; 4 - зливальний бак;

5 - циркуляційний насос; 6 - вентиль для регулювання гідравлічного опору й витрати теплоносія; 7 - проточний термостат; 8 - вхід у СК

Рисунок 1 - Принципова схема лабораторного теплогідравлічного випробувального стенду

Таблиця. Порівняння результатів випробувань полімерних сонячних колекторів

\begin{tabular}{|c|c|c|c|c|c|}
\hline \multirow{3}{*}{ Марка } & \multirow{3}{*}{ Конструкція } & \multicolumn{4}{|c|}{ Випробування } \\
\hline & & \multicolumn{2}{|c|}{ Натурні* } & \multicolumn{2}{|c|}{$\begin{array}{l}\text { Лабора- } \\
\text { торні** }\end{array}$} \\
\hline & & $\mathrm{F}^{\prime}(\tau \alpha)$ & $\mathrm{F}^{\prime} \mathrm{U}_{\mathrm{L}}$ & $\mathrm{F}^{\prime}(\tau \alpha)$ & $\mathrm{F}^{\prime} \mathrm{U}_{\mathrm{L}}$ \\
\hline $\begin{array}{l}\text { ПСК- } \\
\text { АВ2-3 }\end{array}$ & \begin{tabular}{l|l|l|} 
& 1 \\
\end{tabular} & 0,57 & 1,05 & 0,59 & 0,97 \\
\hline $\begin{array}{l}\text { ПСК- } \\
\text { AB } 1-2\end{array}$ & 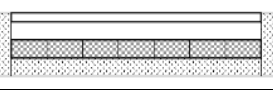 & 0,74 & 5,33 & 0,76 & 4,44 \\
\hline $\begin{array}{l}\text { ПСК- } \\
\text { АB2-1 }\end{array}$ & $t_{1}+1+1$ & 0,84 & 8,78 & 0,86 & 8,65 \\
\hline $\begin{array}{l}\text { ПСК- } \\
\text { ВC1-2 }\end{array}$ & $\begin{array}{ll} \\
-1\end{array}$ & 0,73 & 4,93 & 0,75 & 4,11 \\
\hline $\begin{array}{l}\text { ПСК- } \\
\text { ВС2-2 }\end{array}$ & 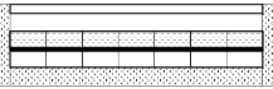 & 0,73 & 4,84 & 0,75 & 4,13 \\
\hline $\begin{array}{l}\text { ПСК- } \\
\text { ВC2-3 }\end{array}$ & \begin{tabular}{|l|l|l|} 
\\
+
\end{tabular} & 0,56 & 0,74 & 0,59 & 0,75 \\
\hline $\begin{array}{c}\text { ПСК- } \\
\text { СТ10- } \\
\text { ЧВ }\end{array}$ & 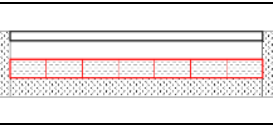 & 0,63 & 5,37 & 0,64 & 4,99 \\
\hline
\end{tabular}

Примітка: * для натурних випробувань розкид даних складає 4-7\%;

** для лабораторних випробувань розкид даних складає $3-5 \%$

Миттєвий ККД визначається відношенням питомої теплопродуктивності до густини потоку сонячного ви- промінювання в площині колектора, а оптичний ККД $\mathrm{F}^{\prime}(\tau \alpha)$ - питомої теплопродуктивності до густини потоку сонячного випромінювання при однакових температурах теплоносія та навколишнього середовища, а приведений коефіцієнт теплових втрат $\mathrm{F}^{\prime} \mathrm{U}_{\mathrm{L}}-$ як добуток коефіцієнта ефективності сонячного колектора та повного коефіцієнту теплових втрат.

Проведені випробування колекторів, виготовлених зі стільникових полікарбонатних пластиків (таблиця), які захищено патентами України [5 - 8]. В якості прозорої ізоляції використовувався одноярусний прозорий стільниковий полікарбонатний пластик товщиною 4 мм та двоярусний прозорий стільниковий полікарбонатний пластик товщиною 14 мм.

Абсорбер виконувався на основі двоярусного прозорого стільникового полікарбонатного пластику товщиною 14 мм та одноярусного стільникового полікарбонатного пластику товщиною 10 мм прозорого та червоного відтінку, колірного тону 572' та 625 нм з чистотою кольору відповідно 3 й 38\%. В якості поглинача сонячного випромінювання використовувалася вуглецева стрічка, гранули активованого вугілля та власне одноярусний стільниковий полікарбонатний пластик червоного кольору (колірний тон 625 нм, чистота кольору $38 \%$ ), а в ролі корпуса СК - листи полівінілхлориду (ПВХ). Полімерні СК теплоізолювалися листовим пінополіуретаном (товщиною 50 та 30 мм, густиною

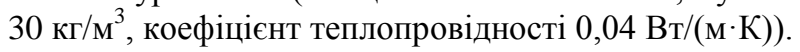

\section{3 Результати та обговорення}

Експериментальні результати надані в вигляді залежностей ККД колектора від приведеної температури, яка дорівнює відношенню різниці між температурою теплоносія $\mathrm{T}_{\mathrm{a}}$ та навколишнього середовища $\mathrm{T}_{\mathrm{f}}$ до інте- 
нсивності сонячного випромінювання, які при постійних теплових втратах $\mathrm{U}_{\mathrm{L}}=$ const $\mathrm{i}$ коефіцієнті ефективності $\mathrm{F}^{\prime}=$ const $€$ лінійними залежностями (рис. 2).

Для підігріву води в басейнах, гарячого водопостачання та інших технологічних потреб, зокрема, регенерації композитів 3 температурою регенерації на рівні 50 - $60^{\circ} \mathrm{C}$ середня температура абсорбера повинна на 20 35 К перевищувати температуру навколишнього середовища, що при середній інтенсивності сонячного випромінювання в $850 \mathrm{BT} / \mathrm{m}^{2}$ відповідає характерному, для даних цілей, діапазону приведеної температури 0,024-

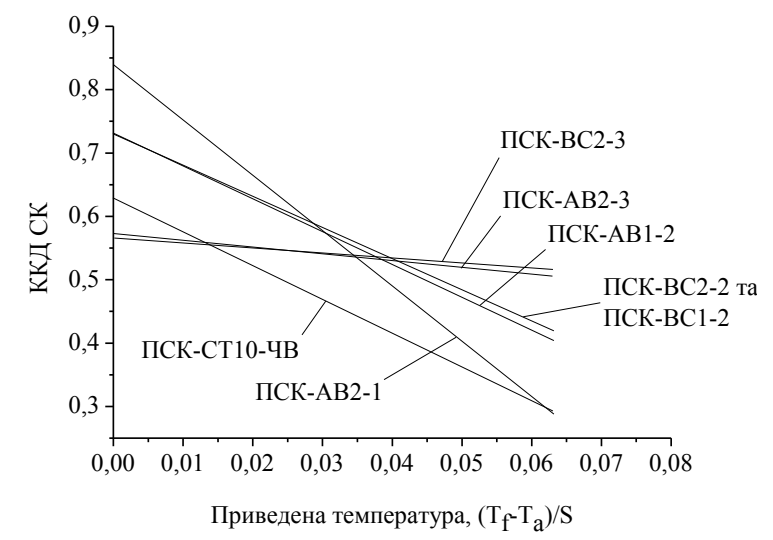

a

Рисунок 2 - Залежності ККД розроблених полімерних СК від приведеної температури: а - натурні випробування; б - лабораторні випробування $0,059\left(\mathrm{M}^{2} \cdot \mathrm{K}\right) /$ Вт та вище. квадратів.

б
0,041 (м².К)/Вт. Для десорбції води з сорбентів з температурою регекнерації більше $80^{\circ} \mathrm{C}$ температура теплоносія повинна бути вищою ніж температура навколишнього середовища на 40-50 К. Отже, характерною ділянкою приведених температур можна вважати $\mathrm{T}_{\text {пр }}=0,047-$

На рис. 2 наведені теплотехнічні характеристики розроблених СК у вигляді кривих отриманих шляхом апроксимації експериментальних даних методом найменших

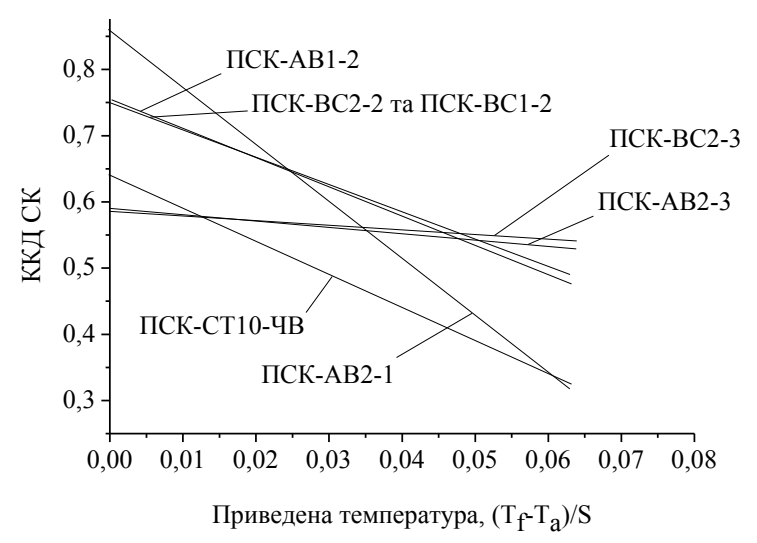

показники приведених теплових втрат $\mathrm{F}^{\prime} \mathrm{U}_{\mathrm{L}}=0,74-1,05$ $\mathrm{BT} /\left(\mathrm{M}^{2} \cdot \mathrm{K}\right)$.

Конструкції полімерних СК, ПСК-АВ1-2, ПСК-ВС2-2 й ПСК-ВС1-2 з оптичним ККД $\mathrm{F}^{\prime}(\tau \alpha)=0,73-0,74$ та 3 приведеними тепловими втратами $\mathrm{F}^{\prime} \mathrm{U}_{\mathrm{L}}=4,84$ $5,33 \mathrm{BT} /\left(\mathrm{м}^{2} \cdot \mathrm{K}\right)$, ефективно використовувати для цілорічних геліосистем.

Найбільш високий оптичний ККД має ПСК-АВ2-1 $\left(\mathrm{F}^{\prime}(\tau \alpha)=0,84\right) \in$ результатом наявністю лише одного шару прозорої ізоляції та високим коефіцієнтом поглинання активованого вугілля $(\alpha=0,98)$. Не високий оптичний ККД конструкції ПСК-СТ10-ЧВ в порівнянні з ПСКAB2-1 пояснюється меншим на 23 \% коефіцієнтом поглинання та збільшенням на один шар прозорої ізоляції. Це приводить до зменшення приведених теплових втрат на $39 \%\left(\mathrm{~F}^{\prime} \mathrm{U}_{\mathrm{L}}=5,37 \mathrm{BT} /\left(\mathrm{M}^{2} \cdot \mathrm{K}\right)\right)$. У діапазоні приведених температур 0,024-0,041 ( $\left.\mathrm{m}^{2} \cdot \mathrm{K}\right) / \mathrm{B}$, ці колектори мають досить високий ККД на рівні $0,41-0,63$. Дані конструкції $\epsilon$ перпективними для отримання не високих температур, наприклад, i, отже, можуть бути використані при використанні сорбентів 3 температурами регенерації в інтервалі $50-60^{\circ} \mathrm{C}$.

Отримані теплотехнічні характеристики (рис. 2) дозволяють зробити висновки, що такі конструкції як ПСКВС2-3 та ПСК-АВ2-3 перспективно використовувати в якості сезонних геліосистем, які можуть ефективно працювати у зимовий період, для систем опалення та інших технологічних потреб, де температура теплоносія перевищує температуру навколишнього середовища більше ніж на $40-50^{\circ} \mathrm{C}$. Низький оптичний ККД ПСК-ВС2-3 ками крашими є ПСК-ВС2-3, ПСК-АВ2-3, які мають найвищі показники ККД 0,56-0,54 та найбільш низькі 
$\mathrm{F}^{\prime}(\tau \alpha)=0,56$ та ПСК-АВ2-3 $\mathrm{F}^{\prime}(\tau \alpha)=0,57$ пояснюється наявністю потрійного шару прозорої ізоляції. Так як ступінь чорноти вуглецевої стрічки приймалася 0,77 відповідно оптичний ККД ПСК-ВС2-3 на $2 \%$ менший за ККД ПСК-АВ2-3. 3 іншої сторони потрійна прозора ізоляція зменшує приведені теплові втрати до позначки $\mathrm{F}^{\prime} \mathrm{U}_{\mathrm{L}}=0,74 \quad \mathrm{BT} /\left(\mathrm{M}^{2} \cdot \mathrm{K}\right) \quad$ для ПСК-ВС2-3 та $\mathrm{F}^{\prime} \mathrm{U}_{\mathrm{L}}=1,05 \mathrm{BT} /\left(\mathrm{м}^{2} \cdot \mathrm{K}\right)$ для ПСК-АВ2-3.

Сонячні колектори конструкцій ПСК-АВ1-2, ПСКВС2-2 та ПСК-ВС1-2 можуть ефективно використовуватися в адсорбційних холодильних геліосистемах при використанні композитів 3 температурою регенерації більш за $80^{\circ} \mathrm{C}$ тобто у діапазоні приведених температур 0,041-0,059 $\left(\mathrm{м}^{2} \cdot \mathrm{K}\right) /$ Вт. Їхні теплотехнічні параметри знаходяться практично на одному рівні. Оптичні ККД для ПСК-АВ1-2, ПСК-ВС2-2 й ПСК-ВС1-2 знаходяться на рівні $\mathrm{F}^{\prime}(\tau \alpha)=0,74$. Експериментальні дані довели ефективність розробленої конструкції ПСК-ВС2-2, яка дозволяє зменшити вартість та габаритні розміри СК без суттєвої зміни його теплотехнічних характеристик. Це можливо зробити за рахунок використання двоярусного прозорого стільникового полікарбонатного пластика, нижній ярус якого заповнюється повітрям, що дозволяє зменшити товщину теплоізоляційного матеріалу з 50 мм до 30 мм без суттєвих змін теплотехнічних характеристик (які практично виходять на ті ж самі значення, що має конструкція ПСК-ВС1-2).

Розроблені конструкції полімерних СК за теплотехнічними параметрами не поступаються СК різних виробників, зокрема, металевого СК „Сокол” виробництва HBO „Машиностроение”, РФ [3]; вакуумного Thermomax Ltd., модель MAZDON TMA 600 S [19], а колектори конструкцій ПСК-АВ1-2, ПСК-АВ2-1, ПСКВC2-2 ПСК-ВС1-2, ПСК-ВС2-3 та ПСК-АВ2-3 перевищують їх.

Так оптичний ККД для досліджуваних конструкцій полімерних СК знаходиться у діапазоні від 0,59 до 0,86, а приведений коефіцієнт теплових втрат складає від 0,75 до $8,65 \mathrm{BT} /\left(\mathrm{M}^{2} \cdot К\right)$. Оптичний ККД вже існуючих полімерних СК становить 0,62-0,78, кращих металевих 0,720,74, а вакуумних $-0,53-0,58$.

В діапазоні приведених температур 0,024$0,041\left(\mathrm{M}^{2} \cdot \mathrm{K}\right) /$ Вт розроблені полімерні СК на основі стільникових полікарбонатних пластиків (ПСК-АВ2-1, ПСКСТ10-ЧВ) мають ККД на рівні 0,44-0,66, що перевищує ККД найбільш ефективних промислових полімерних СК $(0,3-0,54)$ [9] та відповідає ККД кращих металевих СК $(0,51-0,6)[3]$, та перевищує ККД стандартних вакуумних СК $(0,51-0,54)$ у даних умовах експлуатації [9].

Інші конструкції розроблених полімерних СК (ПСКAB2-3, ПСК-ВС2-3), згідно з результатами лабораторних випробувань, мають доволі низькі значення приведеного коефіцієнта теплових втрат - на рівні 0,75$0,97 \mathrm{BT} /\left(\mathrm{м}^{2} \cdot \mathrm{K}\right)$. Це супроводжується збільшенням ККД у характерній ділянці приведених температур 0,0470,059 $\left(\mathrm{м}^{2} \cdot \mathrm{K}\right) /$ Вт до 0,53-0,54, що свідчить про доцільність використання подібних конструкцій у сезонних геліосистемах, які можуть ефективно працювати в умовах, якщо температура теплоносія перевищує температуру навколишнього середовища більше ніж на $40-50^{\circ} \mathrm{C}$.
ККД розроблених конструкцій ПСК-АВ2-1 та ПСКСТ10-ЧВ, у діапазоні приведених температур 0,024$0,041\left(\mathrm{м}^{2} \cdot \mathrm{K}\right) / \mathrm{BT}$, на $14-21 \%$ вищий за, вже існуючі полімерні СК, а деякі знаходяться практично на одному й тому ж рівні (ПСК №4 та ПСК-СТ10-ЧВ). ККД ПСКАВ2-1 знаходиться практично на рівні ККД металевого СК „Сокол” виробництва НПО „Машиностроение”, РФ $(0,56-0,63)$. ККД стандартного вакуумного СК (GREENone Tес, модель VK 29) при приведеній темпеpaтурі $0,024\left(\mathrm{M}^{2} \cdot \mathrm{K}\right) /$ Вт поступається ККД конструкції ПСК-СТ10-ЧВ на $1 \%$, а ПСК-АВ2-1 на $14 \%$. При цьому, ККД вакуумного СК MAZDON TMA 600 S менше на $1 \%$ за ККД ПСК-АВ2-1 та більше ККД ПСКСТ10-ЧВ на $2 \%$. При приведеній температурі

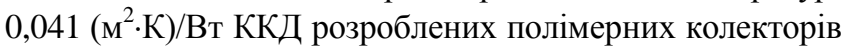
знаходиться практично на одному рівні.

При порівнянні цілорічних геліосистем (ПСК-АВ1-2, ПСК-ВС2-2 й ПСК-ВС1-2) із відомими полімерними СК можна зробити висновок про те, що при приведеній температурі 0,024 $\left(\mathrm{m}^{2} \cdot \mathrm{K}\right) / \mathrm{B}$ дані конструкції мають ККД вищий на 11-16 \% за ККД вже існуючих полімерних СК різних виробників, а при приведеній температурі $0,059\left(\mathrm{м}^{2} \cdot \mathrm{K}\right) / \mathrm{BT}-$ вищий на $15-41 \%$. При порівнянні 3 конструкціями кращих металевих СК дані конструкції у діапазоні приведених температур 0,024-0,059 ( $\left.\mathrm{M}^{2} \cdot \mathrm{K}\right) / \mathrm{BT}$ мають миттєвий ККД вищий на 5-9 \% або практично на рівні із ККД конструкції металевого СК „Сокол”, виробництва НПО „Машиностроение” (РФ) [3]. Порівнюючи ККД розроблених конструкцій із вакуумними СК (GREENone Тес, модель VK 29 та MAZDON TMA $600 \mathrm{~S})$, при значенні приведеної температури $0,024\left(\mathrm{M}^{2} \cdot \mathrm{K}\right) / \mathrm{B}$, можна помітити перевагу ККД полімерних на рівні 11-14\%, а при значенні приведеної температури $0,059\left(\mathrm{M}^{2} \cdot \mathrm{K}\right) / \mathrm{B}$ ККД розроблених полімерних СК практично знаходиться на одному і тому ж рівні $( \pm 1 \%)$.

Полімерні СК таких конструкцій, як ПСК-ВС2-3 та ПСК-АВ2-3, у характерній ділянці приведеної температури $\mathrm{T}_{\text {пр }}=0,047-0,059\left(\mathrm{M}^{2} \cdot \mathrm{K}\right) /$ Вт, мають ККД на $13-43 \%$ вищий за ККД існуючих полімерних СК. Теплотехнічні характеристики ПСК-ВС2-3 та ПСК-АВ2-3 у даному діапазоні приведених температур переважають стандартні металеві СК [3]) на 7-11\%. При цьому, ККД при приведеній температурі $0,047 \quad\left(\mathrm{M}^{2} \cdot \mathrm{K}\right) / \mathrm{BT}$ практично знаходяться на одному рівні із ККД металевого СК „Сокол”, виробництва НПО „Машиностроение” (РФ). А при значенні приведеної температури $-0,059\left(\mathrm{M}^{2} \cdot \mathrm{K}\right) / \mathrm{BT}$ та вище, теплотехнічні характеристики розроблених СК переважають ККД металевого СК „Сокол” на 4-6 \%. У даному діапазоні приведених температур вакуумні СК поступаються розробленим полімерним на 3-6 \%.

Суттєва перевага вакуумних СК починає проявлятися лише при приведених температурах більше за $0,06\left(\mathrm{M}^{2} \cdot \mathrm{K}\right) /$ Вт при яких суттєво збільшуються загальні теплові втрати в навколишнє середовище.

\section{Висновки}

Результати лабораторних сонячних колекторів дозволили визначити наступні теплотехнічні параметри:

- ПСК-АВ2-3: $\mathrm{F}^{\prime}(\tau \alpha)=0,59 ; \mathrm{F}^{\prime} \mathrm{U}_{\mathrm{L}}=0,97 \mathrm{BT} /\left(\mathrm{m}^{2} \cdot \mathrm{K}\right)$;

- ПСК-АВ1-2: $\mathrm{F}^{\prime}(\tau \alpha)=0,76 ; \mathrm{F}^{\prime} \mathrm{U}_{\mathrm{L}}=4,44 \mathrm{BT} /\left(\mathrm{м}^{2} \cdot \mathrm{K}\right)$; 
- ПСК-АВ2-1: $\mathrm{F}^{\prime}(\tau \alpha)=0,86 ; \mathrm{F}^{\prime} \mathrm{U}_{\mathrm{L}}=8,65 \mathrm{BT} /\left(\mathrm{m}^{2} \cdot \mathrm{K}\right)$;

- ПСК-ВС1-2: $\mathrm{F}^{\prime}(\tau \alpha)=0,75 ; \mathrm{F}^{\prime} \mathrm{U}_{\mathrm{L}}=4,11 \mathrm{BT} /\left(\mathrm{M}^{2} \cdot \mathrm{K}\right)$;

- ПСК-ВС2-2: $\mathrm{F}^{\prime}(\tau \alpha)=0,75 ; \mathrm{F}^{\prime} \mathrm{U}_{\mathrm{L}}=4,13 \mathrm{BT} /\left(\mathrm{m}^{2} \cdot \mathrm{K}\right)$;

- ПСК-ВС2-3: $\mathrm{F}^{\prime}(\tau \alpha)=0,59 ; \mathrm{F}^{\prime} \mathrm{U}_{\mathrm{L}}=0,75 \mathrm{BT} /\left(\mathrm{m}^{2} \cdot \mathrm{K}\right)$;

- ПСК-СТ10-ЧВ: $\mathrm{F}^{\prime}(\tau \alpha)=0,64 ; \mathrm{F}^{\prime} \mathrm{U}_{\mathrm{L}}=4,99 \mathrm{Bт} /\left(\mathrm{m}^{2} \cdot \mathrm{K}\right)$

Розбіжність між результатами лабораторних та натурних випробувань не перевищує $5-7 \%$

При температурі регенерації композитного сорбенту до $50-60^{\circ} \mathrm{C}$ доцільно використовувати колектори типу ПСК-АВ2-1, ПСК-СТ10-ЧВ, а при температурах, вище $80^{\circ} \mathrm{C}$ - типів ПСК-АВ2-3, ПСК-ВС2-3, ПСК-АВ1-2, ПСК-ВС2-2 та ПСК-ВС1-2.

\section{Література}

1. Review of alternative cooling technologies / J. Steven Brown, Piotr A. Domanski // Applied Thermal Engineering. - 2014. - V.64, I. 1-2. - Pages 252 - 262.

2. Review and future trends of solar adsorption refrigeration systems / M.S. Fernandes, G.J.V.N. Brites, J.J. Costa, A.R. Gaspar, V.A.F. Costa // Renewable and Sustainable Energy Reviews. - 2014. - V. 39. - P. $102-123$.

3. Сулейманов М.Ж. Экспериментальное исследование теплотехнических характеристик солнечных коллекторов и водонагревательных установок [Текст] : автореф. дис...канд. техн. наук: 05.14.01 / М.Ж. Сулейманов; [Объединенный институт высоких температур РАН]. M., 2007. -26 c.

4. Пат. 55715 А Україна, МПК F24J 2/24 (2006.01). Теплогідравлічний випробувальний стенд [Текст] / Сухий М. П., Козлов Я. Н., Сухий К. М. (Україна); заявник та патентовласник держ. вищ. навч. заклад „Укр. держ. хім.-техн. ун-т." - № и 2010 06369; заявл. 25.05.10; опубл. 27.12.10, Бюл. № 24. - 6 c.

5. Пат. 41237 А Україна, МПК (2006.01) F24J 2/06. Сонячний колектор [Текст] / Сухий М. П., Козлов Я. Н., Сухий К. М. (Україна); заявник та патентовласник держ. вищ. навч. заклад „Укр. держ. хім.-техн. ун-т.” № u 2008 14843; заявл. 23.12.08 ; опубл. 12.05.09, Бюл. № $9 .-4 \mathrm{c}$.

6. Пат. 53852 А Україна, МПК (2006.01) F24J 2/00, F24J 2/04, F24J 2/06. Сонячний колектор [Текст] / Сухий М. П., Козлов Я. Н., Сухий К. М. (Україна); заявник та патентовласник держ. вищ. навч. заклад „Укр. держ. хім.-техн. ун-т." - № u 2010 02818; заявл. 12.03.10 ; опубл. 25.10.10, Бюл. № 20. -4 с.

7. Пат. 53853 А Україна, МПК (2006.01) F24J 2/00, F24J 2/04, F24J 2/06 (2006.01). Сонячний колектор [Текст] / Сухий М. П., Козлов Я. Н., Сухий К. М. (Україна); заявник та патентовласник держ. вищ. навч. заклад „Укр. держ. хім.-техн. ун-т.” - № u 2010 02819; заявл. 12.03 .10 ; опубл. 25.10 .10 , Бюл. № 20. -6 c.

8. Пат. 53855 А Україна, МПК (2006.01) F24J 2/00, F24J 2/04, F24J 2/06. Сонячний колектор [Текст] / Сухий М. П., Козлов Я. Н., Сухий К. М. (Україна); заявник та патентовласник держ. вищ. навч. заклад „Укр. держ. хім.-техн. ун-т.” - № u201002823; заявл. 12.03 .10 ; опубл. 25.10 .10 , Бюл. № 20. - 4 с.

9. Шестопалов К.А. Теплотехнические характеристики полимерных солнечных коллекторов для систем теплоснабжения [Текст] : дис...канд. техн. Наук : $05.14 .06 /$ К.А. Шестопалов. - Одесса, 2005. - 174 с.

Отримана в редакції 22.12.2017, прийнята до друку 07.02.2018

\title{
Operating characteristics of polymeric solar collectors for adsorptive chilling solar plants
}

\author{
K.M. Sukhyy ${ }^{a}$, Ya.M. Kozlov ${ }^{a}$, E.A. Belyanovskaya ${ }^{a}$, E.M. Prokopenko ${ }^{\sigma}$, I.V. Sukha ${ }^{a}$, A.V. Doroshenko ${ }^{6}$ \\ ${ }^{a}$ State Higher Education Institition 'Ukrainian State University for Chemical Engineering', Dnipro \\ ${ }^{6}$ National Metallurgic Academy of UkraineУкраїни, Dnipro

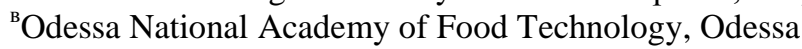

\begin{abstract}
The operating characteristics of solar collectors made of cellular polycarbonate plastics for adsorption chilling units have been studied. Instantaneous efficiency coefficient is calculated as special thermal performance-solar radiant flux surface density ratio, optical efficiency factor is determined as special thermal performance-solar radiant flux surface density ratio at the equal temperatures of heat transfer medium and environment, reduced heat loss factor being calculated as the product of solar collector efficiency factor and net heat loss coefficient. The environmental test of developed collectors PSK-AV2-3, PSK-AV1-2, PSK-AV2-1, PSK-VS1-2, PSK-VS2-2, PSK-VS2-3, PSK-ST10-PW were conducted. The correlation of their results with laboratory tests when the thermohydraulic stand applied is shown. Relative accuracy of laboratory and environment tests is shown to be not exceeding $5-7 \%$. The determined optical efficiency factor and the coefficient of thermal losses of polymeric solar collectors, \% and W/m2 $\cdot K$ : PSK-AB2-3 59 and 0,97, PSK-AB1-2 76 and 4,44, PSK-AB2-1 - 86 and 8.65, PSK-VS1-2-75 and 4.11, PSK-VS2-2-75 and 4.13, PSK-VS2-3-59 and 0.75, PSK-ST10-PW-64 and 4.99. On the basis of the dependencies of the efficiency of the solar collectors vs. the reduced temperature, optimal designs of the polymeric solar collectors for the adsorption chilling solar systems are determined to be depended on the temperature of the regeneration temperature of the sorbents. As the temperatures of the regeneration of composite sorbent ranged from $50^{\circ} \mathrm{C}$ to $60^{\circ} \mathrm{C}$, appliance of the collectors PSK-AV2-1, PSK-CT10-PW is shown to be expedient to use type, and PSK-AB2-3, PSK-VS2-3, PSK-AB1-2, PSK-VS2-2 and PSK-VS1-2 are revealed to be more efficient when regeneration temperatures increased over $80{ }^{\circ} \mathrm{C}$. Thermotechnical characteristics of designed polymeric solar collectors are shown to exceed traditional metal and vacuum collectors at the reduced tem-
\end{abstract}


peratures less than $0.06 \mathrm{~m} 2 \bullet \mathrm{K} / \mathrm{W}$. The perspectives of polymeric solar collectors in the design of adsorptive chilling solar plants are shown.

Key words: adsorptive chilling solar plant, polymeric solar collector, cellular polycarbonate plastic.

\section{References}

1. Review of alternative cooling technologies / J. Steven Brown, Piotr A. Domanski // Applied Thermal Engineering. - 2014. - V.64, I. 1-2. - Pages $252-262$.

2. Review and future trends of solar adsorption refrigeration systems / M.S. Fernandes, G.J.V.N. Brites, J.J. Costa, A.R. Gaspar, V.A.F. Costa // Renewable and Sustainable Energy Reviews. - 2014. - V. 39. - P. $102-123$.

3. Suleimanov M.Zh. Эksperymentalnoe issledovanye teplotekhnycheskykh kharakterystyk solnechnukh kollektorov y vodonahrevatelnukh ustanovok [Tekst] : avtoref. dys...kand. tekhn. nauk: 05.14.01 / M.Zh. Suleimanov; [Obъedynennыi ynstytut vыsokykh temperatur RAN]. - M., 2007. - $26 \mathrm{~s}$.

4. Pat. 55715 A Ukraina, MPK F24J 2/24 (2006.01). Teplohidravlichnyi vyprobuvalnyi stend [Tekst] / Sukhyi M. P., Kozlov Ya. N., Sukhyi K. M. (Ukraina); zaiavnyk ta patentovlasnyk derzh. vyshch. navch. zaklad „Ukr. derzh. khim.-tekhn. un-t.” - № u 2010 06369; zaiavl. 25.05.10; opubl. 27.12.10, Biul. № 24. $-6 \mathrm{~s}$.

5. Pat. 41237 A Ukraina, MPK (2006.01) F24J 2/06. Soniachnyi kolektor [Tekst] / Sukhyi M. P., Kozlov Ya. N., Sukhyi K. M. (Ukraina); zaiavnyk ta patentovlasnyk derzh. vyshch. navch. zaklad „Ukr. derzh. khim.-tekhn. un-t.” - № u 2008 14843; zaiavl. 23.12.08; opubl. 12.05.09, Biul. № 9. $-4 \mathrm{~s}$.
6. Pat. 53852 A Ukraina, MPK (2006.01) F24J 2/00, F24J 2/04, F24J 2/06. Coniachnyi kolektor [Tekst] / Sukhyi M. P., Kozlov Ya. N., Sukhyi K. M. (Ukraina); zaiavnyk ta patentovlasnyk derzh. vyshch. navch. zaklad „Ukr. derzh. khim.-tekhn. un-t.” - № u 2010 02818; zaiavl. 12.03.10 ; opubl. 25.10.10, Biul. № 20. -4 s.

7. Pat. 53853 A Ukraina, MPK (2006.01) F24J 2/00, F24J 2/04, F24J 2/06 (2006.01). Soniachnyi kolektor [Tekst] / Sukhyi M. P., Kozlov Ya. N., Sukhyi K. M. (Ukraina); zaiavnyk ta patentovlasnyk derzh. vyshch. navch. zaklad „Ukr. derzh. khim.-tekhn. un-t.” - № u 2010 02819; zaiavl. 12.03.10 ; opubl. 25.10.10, Biul. № 20. - 6 s.

8. Pat. 53855 A Ukraina, MPK (2006.01) F24J 2/00, F24J 2/04, F24J 2/06. Coniachnyi kolektor [Tekst] / Sukhyi M. P., Kozlov Ya. N., Sukhyi K. M. (Ukraina); zaiavnyk ta patentovlasnyk derzh. vyshch. navch. zaklad „Ukr. derzh. khim.-tekhn. un-t.” - № u201002823; zaiavl. 12.03.10 ; opubl. 25.10.10, Biul. № 20. - 4 s.

9. Shestopalov K.A. Teplotekhnycheskye kharakterystyky polymernыkh solnechnokh kollektorov dlia system teplosnab-zhenyia [Tekst] : dys...kand. tekhn. Nauk : 05.14.06 / K.A. Shestopalov. - Odessa, 2005. - 174 s.

Received 12 December 2017 Approved 07 February 2018 Available in Internet 28 February 2018 